G. V. Grygoriv, D. A. Lega, L. M. Shemchuk, L. M. Maloshtan, G. S. Kalenichenko,

V. P. Chernykh, L. A. Shemchuk

National University of Pharmacy

\title{
The synthesis of 2-amino-4-aryl-4H-pyrano[3,2-c][1,2] benzoxathiine-3-carbonitrile 5,5-dioxides and the study of their effect on the blood coagulation process
}

To date, coumaric oral anticoagulants are the worldwide standard for thrombosis treatment. However, representatives of this group also possess a number of undesirable side effects; therefore, the search for novel anticoagulants are still in progress.

Aim. To synthesize 2-amino-4-aryl-4H-pyrano[3,2-c][1,2]benzoxathiine-3-carbonitrile 5,5-dioxides and study their effect on the blood coagulation process.

Results and discussion. Reflux of equimolar quantities of 1,2-benzoxathiin-4(3H)-one 2,2-dioxide with malononitrile and arenecarbaldehydes for $1 \mathrm{~h}$ in ethanol with the catalytic amount of triethylamine led to formation of 2-amino4-aryl-4H-pyrano[3,2-c][1,2]benzoxathiine-3-carbonitrile 5,5-dioxides. A wide range of substituted aromatic aldehydes was used for further study of the "structure - biological activity" relationship. Among the compounds synthesized substances with anticoagulant and hemostatic properties were found.

Experimental part. A series of 2-amino-4-aryl-4H-pyrano[3,2-c][1,2]benzoxathiine-3-carbonitrile 5,5-dioxides was synthesized. The effect of the compounds obtained on the blood coagulation process was studied in vitro by the Burker method.

Conclusions. The target 2-amino-4-aryl-4H-pyrano[3,2-c][1,2]benzoxathiine-3-carbonitrile 5,5-dioxides can be easily obtained with moderate to high yields in the three-component interaction of 1,2-benzoxathiin-4(3H)-one 2,2-dioxide, malononitrile and arenecarbaldehydes. According to the in vitro studies both anticoagulant and hemostatic substances with relatively high levels of the activities were found among this novel heterocyclic group of compounds. Thus, the effect of 2-amino-4-aryl-4H-pyrano[3,2-c][1,2]benzoxathiine-3-carbonitrile 5,5-dioxides on the blood coagulation process requires further detailed study.

Key words: 1,2-benzoxathiin-4(3H)-one 2,2-dioxide; aromatic aldehydes; malononitrile; $4 H$-pyran; anticoagulant activity; hemostatic activity

Г. В. Григорів, Д. О. Лега, Л. М. Шемчук, Л. М. Малоштан, Г. С. Каленіченко, В. П. Черних,

Л. А. Шемчук

Синтез 2-аміно-4-арил-4H-пірано[3,2-с][1,2]бензоксатіїн-3-карбонітрил

5,5-діоксидів та вивчення їх впливу на процес згортання крові

Сучасні оральні антикоагулянти кумаринового ряду є світовим стандартом у лікуванні тромбозів. Проте препарати даної групи мають ряд побічних ефектів, а тому актуальним є пошук нових безпечних антикоагулянтів.

Мета. Синтезувати 2-аміно-4-арил-4Н-пірано[3,2-с][1,2]бензоксатіїн-3-карбонітрил 5,5-діоксиди та дослідити їх вплив на процес згортання крові.

Результати та їх обговорення. Взаємодія еквімолярних кількостей 1,2-бензоксатіїн-4(3Н)-он 2,2-діоксиду з малонодинітрилом та бензальдегідами при кип'ятінні впродовж 1 години в етанолі в присутності каталітичної кількості триетиламіну приводила до утворення 2-аміно-4-арил-4H-пірано[3,2-c][1,2]бензоксатіїн-3-карбонітрил 5,5-діоксидів. У дослідженні було використано широкий ряд заміщених ароматичних альдегідів 3 метою подальшого вивчення залежності «структура-біологічна активність». Серед синтезованих сполук були знайдені речовини з антикоагулянтними та кровоспинними властивостями.

Експериментальна частина. Було синтезовано ряд 2-аміно-4-арил-4H-пірано[3,2-с][1,2]бензоксатіїн-3карбонітрил 5,5-діоксидів. Вивчення впливу одержаних сполук на згортання крові проводили in vitro методом Бюркера.

Висновки. В результаті трикомпонентної взаємодії 1,2-бензокстаіін-4(3H)-он 2,2-діоксиду з малонодинітрилом та бензальдегідами з помірними та високими виходами утворюються цільові 2-аміно-4-арил-4H-пірано[3,2-с] [1,2]бензоксатіїн-3-карбонітрил 5,5-діоксиди. Дослідження in vitro виявили серед похідних даного ряду сполуки з вираженими антикоагулянтними та гемостатичними властивостями. Тому особливості впливу 2-аміно-4-арил-4Hпірано[3,2-c][1,2]бензоксатіїн-3-карбонітрил 5,5-діоксидів на згортання крові потребують подальшого вивчення.

Ключові слова: 1,2-бензоксатіїн-4(3Н)-он 2,2-діоксид; бензальдегіди; малонодинітрил; 4Н-піран; антикоагулянти; гемостатики 
Г. В. Григорив, Д. А. Лега, Л. М. Шемчук, Л. Н. Малоштан, А. С. Калениченко, В. П. Черных, Л. А. Шемчук

\section{Синтез 2-амино-4-арил-4H-пиран[3,2-с][1,2]бензоксатиин-3-карбонитрил 5,5-диоксидов и изучение их влияния на процесс свертывания крови}

Современные оральные антикоагулянты кумаринового ряда являются мировым стандартом в лечении тромбозов. Однако препараты данной группы имеют ряд побочных эффектов, поэтому актуальным является поиск новых безопасных антикоагулянтов.

Цель. Синтезировать 2-амино-4-арил-4H-пиран[3,2-с][1,2]бензоксатиин-3-карбонитрил 5,5-диоксиды и исследовать их влияние на процесс свертывания крови.

Результаты и их обсуждение. Взаимодействие эквимолярных количеств 1,2-бензоксатиин-4(3Н)-он 2,2-диоксида с малонодинитрилом и бензальдегидами при кипячении в течение 1 часа в этаноле в присутствии каталитического количества триэтиламина приводило к образованию 2-амино-4-арил-4H-пиран[3,2-с][1,2]бензоксатиин3-карбонитрил 5,5-диоксидов. В исследовании был использован широкий ряд замещенных ароматических альдегидов с целью дальнейшего изучения зависимости «структура-биологическая активность». Среди синтезированных соединений были найдены вещества с антикоагулянтными и кровоостанавливающими свойствами.

Экспериментальная часть. Был синтезирован ряд 2-амино-4-арил-4Н-пиран[3,2-с][1,2]бензоксатиин-3карбонитрил 5,5-диоксидов. Изучение влияния полученных соединений на свертываемость крови проводили in vitro методом Бюркера.

Выводы. В результате трехкомпонентного взаимодействия 1,2-бензокстаиин-4(3Н)-он 2,2-диоксида с малонодинитрилом и бензальдегидами с умеренными и высокими выходами образуются целевые 2-амино-4-арил-4Hпиран[3,2-c][1,2]бензоксатиин-3-карбонитрил 5,5-диоксиды. Исследования in vitro обнаружили среди производных данного ряда соединения с выраженными антикоагулянтными и гемостатическими свойствами. Поэтому особенности влияния 2-амино-4-арил-4H-пиран[3,2-с][1,2]бензоксатиин-3-карбонитрил 5,5-диоксидов на свертываемость крови требуют дальнейшего изучения.

Ключевые слова: 1,2-бензоксатиин-4(3Н)-он 2,2-диоксид; бензальдегиды; малонодинитрил; 4 -пиран; антикоагулянты; гемостатики

The process of creating new drugs is closely connected with the search of core-structures with the necessary pharmacological activity. However, the existing or novel core-structures usually cause undesirable side effects, have imperfect pharmacokinetic characteristics, and, therefore, they require further structural optimization. The synthetic modification of the primary structure of biologically active substances is aimed to increase its activity, improve selectivity and reduce toxicity. One of the powerful tools in this regard is the concept of isosterism [1].

For the first time it was formulated by I. Langmuir in 1919 [2]. Later G. Erlenmeyer gave the following definition for the term "isostere": "atoms, ions, or molecules, in which the outer electron shells can be considered as identical" [3]. Comparing the properties of isosteres he considered not only their physical, chemical properties and reactivity, but also the biological activity.

As for the term "bioisosterism", it was proposed in 1951 by G. Friedman [4], who named as bioisosteres all compounds (atoms and molecules) that satisfied the definition of isosteres and had the same biological activity. It is worth mentioning that G. Friedman noted that bioisosteres affected the same biological target, but assumed that their activity could be either similar or antagonistic.

Further development of the bioisosterism concept belongs to C. Hansch [5, 6], one of the founders of the QSAR (quantitative structure-activity relationships) methodology. He defined bioisosteres as "compounds causing an identical biochemical or pharmacological response in a standard system, such as a cell membrane, enzyme, receptor, experimental animal".
In case of a bioisosteric replacement (i.e. changing of a structural part of a molecule with another one that is structurally close to it), one or more of the following molecule characteristics are changed: size, shape, hydrophobicity, solubility, $\mathrm{pK}_{\mathrm{a}}$, reactivity, etc. These alterations give the possibility to increase the selectivity of the compound action, reduce its side effects, improve pharmacokinetic parameters, and the increase metabolic stability.

According to the above information 1,2-benzoxathiin4(3H)-one 2,2-dioxide 1 can be considered as an isostere of such famous pharmacophore as 4-hydroxycoumarin core A (Fig.). The derivatives of the latter revealed a pronounced anticoagulant effect; they reduce blood coagulation by inhibiting vitamin K [7]. On their basis anticoagulant drugs for the treatment and prevention of thrombosis were created. Despite their undisputable effectiveness, coumaric oral anticoagulants have a narrow therapeutic index and are associated with a high risk of major bleeding [8]. Therefore, the task of searching for novel anticoagulants of the similar structure considering isosteric principles remains important.

Previously, we reported that the three-component interaction of 1,2-benzoxathiin-4(3H)-one 2,2-dioxide 1 with malononitrile $\mathbf{2}$ and benzaldehydes $\mathbf{3}$ led to formation of 2-amino-4-aryl- $4 H$-pyrano[3,2-c] [1,2]benzoxathiine3-carbonitrile 5,5-dioxides 4a-e (Scheme) [9]. This interaction proceeded smoothly under reflux of equimolar quantities of reagents in ethanol for $1 \mathrm{~h}$; it was also found that the most suitable catalyst for the reaction was triethylamine.

The aim of the current research was to synthesize a series of new 2-amino-4-aryl-4H-pyrano[3,2-c][1,2] 

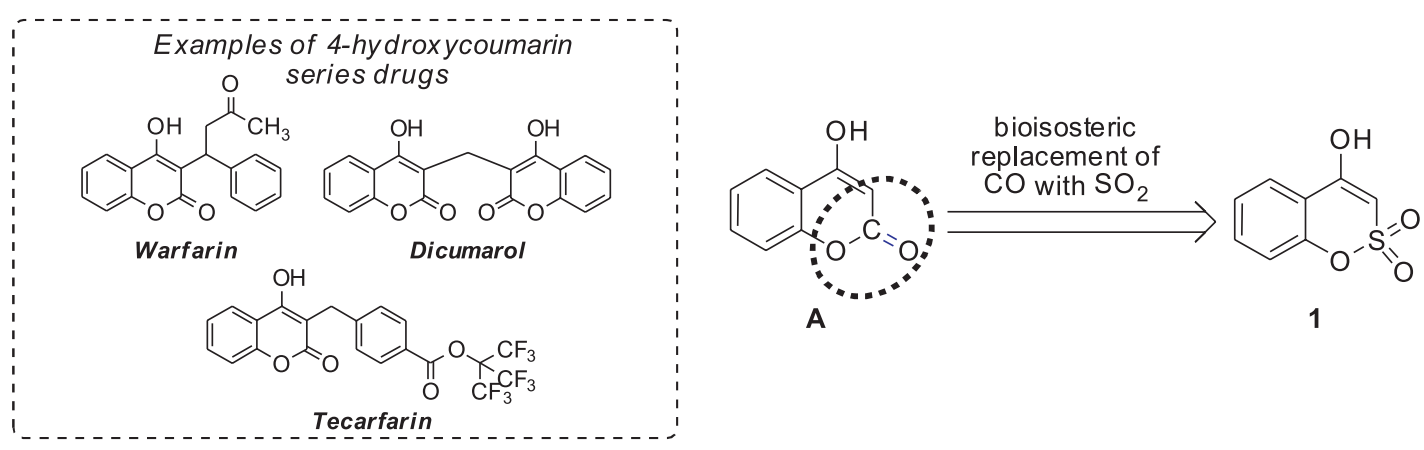

Fig. The bioisosteric relationships between 4-hydroxycoumarin core $\mathbf{A}$ and 1,2-benzoxathiin-4(3H)-one 2,2-dioxide 1

benzoxathiine-3-carbonitrile 5,5-dioxides and study their effect on the blood coagulation process.

\section{Materials and methods}

Experimental chemical part

The starting 1,2-benzoxathiin-4(3H)-one 2,2-dioxide 1 was synthesized according to the procedure [10]. The starting aromatic aldehydes and malononitrile were obtained from commercial sources and used without further purification. Melting points were determined on a Gallenkamp melting point apparatus, Model MFB-595 in open capillary tubes. ${ }^{1} \mathrm{H}$ NMR-spectra of the compounds synthesized were recorded on a Varian WXR-400 spectrometer using DMSO- $\mathrm{d}_{6}$ as a solvent and TMS as an internal standard. Elemental analysis was carried out using a Carlo Erba CHNS-O EA 1108 analyzer.

The general procedure for the synthesis of 2-amino-4-aryl-4H-pyrano[3,2-c][1,2] benzoxathiine-3-carbonitrile 5,5-dioxides (4f-m). To the solution of 1,2-benzoxathiin-4(3H)-one 2,2-dioxide 1 (0.198 g, $0.001 \mathrm{~mol})$, malononitrile $2(0.066 \mathrm{~g}, 0.001 \mathrm{~mol})$ and the corresponding aromatic aldehyde $\mathbf{3} \mathbf{f}-\mathbf{m}(0.001 \mathrm{~mol})$ in ethanol $(5-10 \mathrm{~mL})$ add the catalytic amount of triethylamine. Reflux the mixture for $1 \mathrm{~h}$. Filter the precipitates of compounds $\mathbf{4 f - m}$ obtained, wash with ethanol and then dry on air.

2-Amino-4-(3-chlorophenyl)-4,6-dihydropyrano [3,2-c][2,1]benzoxathiin-3-carbonitrile 5,5-dioxide (4f). A light yellow powder. M. p. $-233-235^{\circ} \mathrm{C}(\mathrm{EtOH})$. Anal. Calcd for $\mathrm{C}_{18} \mathrm{H}_{11} \mathrm{ClN}_{2} \mathrm{O}_{4} \mathrm{~S}, \%$ : C 55.89; H 2.87; N 7.24. Found, \%: C 55.71; H 3.03; N 7.46; ${ }^{1} \mathrm{H} \mathrm{NMR} \mathrm{(400} \mathrm{MHz,}$ DMSO-d $\left.\mathrm{d}_{6}\right): \delta$ (ppm) 7.87-7.94 (m, 2H, Ar); 7.65-7.73 $(\mathrm{m}, 1 \mathrm{H}, \mathrm{Ar}) ; 7.55$ (t, J = $7.78 \mathrm{~Hz}, 1 \mathrm{H}, \mathrm{Ar}) ; 7.50$ (d, $\mathrm{J}=8.24 \mathrm{~Hz}, 1 \mathrm{H}, \mathrm{Ar}) ; 7.46$ (br. s., $2 \mathrm{H}, \mathrm{NH}_{2}$ ); 7.42 (s, 1H, Ar); 7.28-7.38 (m, 2H, Ar); 4.80 (s, 1H, CH).

2-Amino-4-(4-fluorophenyl)-4,6-dihydropyrano [3,2-c][2,1]benzoxathiin-3-carbonitrile 5,5-dioxide (4g). A white fine-crystalline powder. M. p. $-258-260{ }^{\circ} \mathrm{C}$ (EtOH). Anal. Calcd for $\mathrm{C}_{18} \mathrm{H}_{11} \mathrm{FN}_{2} \mathrm{O}_{4} \mathrm{~S}, \%$ : C 58.37; H 2.99; N 7.56. Found, \%: C 58.26; H 2.87; N 7.41; ${ }^{1} \mathrm{H}$ NMR $\left(400 \mathrm{MHz}, \mathrm{DMSO}-\mathrm{d}_{6}\right): \delta(\mathrm{ppm}) 7.88(\mathrm{~d}, \mathrm{~J}=7.32 \mathrm{~Hz}$, 1H, Ar); 7.65-7.71 (m, 1H, Ar); 7.53-7.57 (m, 1H, Ar); 7.47-7.53 (m, 1H, Ar); 7.42 (br. s., 2H, NH $)$ ); 7.38 (dd, $\mathrm{J}=8.24,5.49 \mathrm{~Hz}, 2 \mathrm{H}, \mathrm{Ar}) ; 7.16(\mathrm{t}, \mathrm{J}=8.70 \mathrm{~Hz}, 2 \mathrm{H}, \mathrm{Ar})$ $4.76(\mathrm{~s}, 1 \mathrm{H}, \mathrm{CH})$.

2-Amino-4-(3-fluorophenyl)-4,6-dihydropyrano [3,2-c] [2,1]benzoxathiin-3-carbonitrile 5,5-dioxide (4h). A light yellow powder. M. p. $-205-207^{\circ} \mathrm{C}(\mathrm{EtOH})$. Anal.
Calcd for $\mathrm{C}_{18} \mathrm{H}_{11} \mathrm{FN}_{2} \mathrm{O}_{4} \mathrm{~S}, \%$ : C 58.37; H 2.99; N 7.56. Found, \%: C 58.25; H 3.08; N 7.41; ${ }^{\mathrm{H}} \mathrm{NMR}(400 \mathrm{MHz}$, DMSO-d $\left._{6}\right): \delta(p p m) 7.88(\mathrm{~d}, \mathrm{~J}=7.63 \mathrm{~Hz}, 1 \mathrm{H}, \mathrm{Ar}) ; 7.65-7.72$ (m, 1H, Ar); 7.53-7.58 (m, 1H, Ar); 7.50 (d, J = 8.24 Hz, $1 \mathrm{H}, \mathrm{Ar}$ ); 7.45 (br. s., $2 \mathrm{H}, \mathrm{NH}_{2}$ ); 7.38 (d, J =6.10 Hz, 1H, Ar); 7.30 (d, J = 8.24 Hz, 1H, Ar); 7.16-7.24 (m, 1H, Ar); 7.10 (br. s., 1H, Ar); 4.79 (s, 1H, CH).

2-Amino-4-(4-hydroxyphenyl)-4,6-dihydropyrano [3,2-c] [2,1]benzoxathiin-3-carbonitrile 5,5-dioxide (4i). A white powder. M. p. $-187-190{ }^{\circ} \mathrm{C}(\mathrm{EtOH})$. Anal. Calcd for $\mathrm{C}_{18} \mathrm{H}_{12} \mathrm{~N}_{2} \mathrm{O}_{5} \mathrm{~S}, \%$ : C 58.69; H 3.28; $\mathrm{N} 7.60$. Found, \%: C 58.81; H 3.12; N 7.82; ${ }^{1} \mathrm{H}$ NMR (400 MHz, DMSO-d $)_{6}$ ): $\delta(\mathrm{ppm}) 9.41(\mathrm{~s}, 1 \mathrm{H}, \mathrm{OH}) ; 7.86(\mathrm{~d}, \mathrm{~J}=7.93 \mathrm{~Hz}, 1 \mathrm{H}, \mathrm{Ar})$; 7.64-7.71 (m, 1H, Ar); 7.51-7.56 (m, 1H, Ar); 7.49 (d, $\mathrm{J}=8.24 \mathrm{~Hz}, 1 \mathrm{H}, \mathrm{Ar}) ; 7.31\left(\mathrm{~s}, 2 \mathrm{H}, \mathrm{NH}_{2}\right) ; 7.09(\mathrm{~d}, \mathrm{~J}=8.55 \mathrm{~Hz}$, $2 \mathrm{H}, \mathrm{Ar}) ; 6.70$ (d, J = 8.55 Hz, 2H, Ar); 4.57 (s, 1H, CH).

2-Amino-4-(3-hydroxyphenyl)-4,6-dihydropyrano [3,2-c][2,1]benzoxathiin-3-carbonitrile 5,5-dioxide (4j). A white powder. M. p. $-220-222^{\circ} \mathrm{C}(\mathrm{EtOH})$. Anal. Calcd for $\mathrm{C}_{18} \mathrm{H}_{12} \mathrm{~N}_{2} \mathrm{O}_{5} \mathrm{~S}, \%$ : C 58.69; H 3.28; N 7.60. Found, \%: C 58.53; H 3.41; N 7.44; ${ }^{1} \mathrm{H}$ NMR (400 MHz, DMSO-d ${ }_{6}$ ): $\delta$ (ppm) 9.40 (br. s., 1H, OH); 7.88 (d, J=7.93 Hz, 1H, Ar); 7.63-7.72 (m, 1H, Ar); 7.47-7.57 (m, 2H, Ar); 7.31-7.44 (m, 2H, $\mathrm{NH}_{2}$ ); 7.05-7.19 (m, 2H, Ar); 6.59-6.78 (m, 2H, Ar); 4.59 (s, 1H, CH).

2-Amino-4-(4-trifluoromethylphenyl)-4,6-dihydropyrano[3,2-c] $[2,1]$ benzoxathiin-3-carbonitrile 5,5-dioxide (4k). A white fibrous precipitate. M. p. $>250{ }^{\circ} \mathrm{C}$ (EtOH). Anal. Calcd for $\mathrm{C}_{19} \mathrm{H}_{11} \mathrm{~F}_{3} \mathrm{~N}_{2} \mathrm{O}_{4} \mathrm{~S}, \%$ : C 54.29; H 2.64; N 6.67. Found, \%: C 54.43; H 2.81; N 6.53; ${ }^{1} \mathrm{H}$ NMR (400 MHz, DMSO-d $\left.)_{6}\right): \delta(p p m) 7.90(\mathrm{~d}, \mathrm{~J}=8.55 \mathrm{~Hz}$, 1H, Ar); 7.67-7.75 (m, 3H, Ar); 7.58 (d, J = 8.24 Hz, $2 \mathrm{H}, \mathrm{NH}_{2}$ ); 7.47-7.53 (m, 4H, Ar); 4.90 (s, 1H, CH).

2-Amino-4-(4-methylthiophenyl)-4,6-dihydropyrano[3,2-c] $[2,1]$ benzoxathiin-3-carbonitrile 5,5-dioxide (4l). A yellow fibrous precipitate. M. p. $>250{ }^{\circ} \mathrm{C}$ (EtOH). Anal. Calcd for $\mathrm{C}_{19} \mathrm{H}_{14} \mathrm{~N}_{2} \mathrm{O}_{4} \mathrm{~S}_{2}, \%$ : C 57.27; $\mathrm{H}$ 3.54; N 7.03. Found, \%: C 57.43; H 3.77; N 7.08; ${ }^{1} \mathrm{H}$ NMR (400 MHz, DMSO-d $\left.{ }_{6}\right): \delta(\mathrm{ppm}) 7.83-7.91(\mathrm{~m}$, 1H, Ar); 7.64-7.72 (m, 1H, Ar); 7.53-7.57 (m, 1H, Ar); 7.47-7.53 (m, 1H, Ar); $7.39\left(\mathrm{~s}, 2 \mathrm{H}, \mathrm{NH}_{2}\right) ; 7.17-7.28(\mathrm{~m}$, $4 \mathrm{H}, \mathrm{Ar}) ; 4.68$ (s, $1 \mathrm{H}, \mathrm{CH}) ; 2.46$ (br. s., $3 \mathrm{H}, \mathrm{CH}_{3}$ ).

2-Amino-4-(4-cyanophenyl)-4,6-dihydropyrano [3,2-c][2,1]benzoxathiin-3-carbonitrile 5,5-dioxide (4m). A yellow fine-crystalline powder. M. p. $>250{ }^{\circ} \mathrm{C}(\mathrm{EtOH})$. Anal. Calcd for $\mathrm{C}_{19} \mathrm{H}_{11} \mathrm{~N}_{3} \mathrm{O}_{4} \mathrm{~S}, \%$ : C 60.47; H 2.94; N 11.13. Found, \%: C 60.65; H 2.83; N 11.21; ${ }^{1} \mathrm{H}$ NMR (400 MHz, 


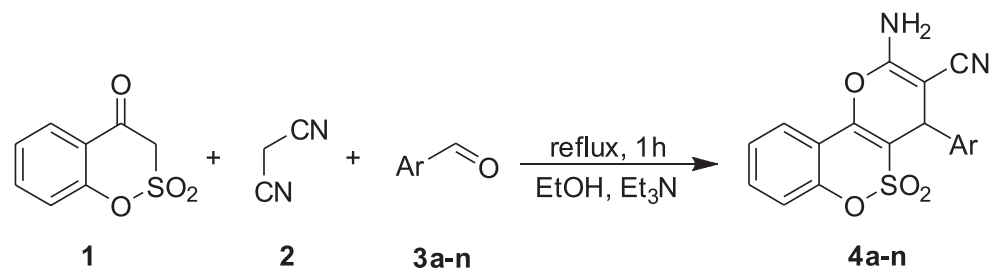

\section{Previously obtained compounds}<smiles>C/C=C\C=C/c1ccccc1C1C(C#N)=C(N)OC2=C1C(c1ccccc1)C(C#N)=C(N)O2</smiles><smiles>COc1ccccc1C1C(C#N)=C(N)Oc2c1c(=O)oc1ccccc21</smiles>
$4 \mathrm{~b}$<smiles>COc1ccccc1C1C(C#N)=C(N)Oc2c1c(=O)oc1ccccc21</smiles><smiles>N#CC1=C(N)OC2=C(Oc3ccccc3O2)C1c1ccc(Cl)cc1</smiles>

\begin{tabular}{c|c|c}
$\mathrm{Cmp}$ & $\mathrm{Ar}$ & Yield, \% \\
\hline $\mathbf{4 f}$ & $3-\mathrm{Cl}-\mathrm{C}_{6} \mathrm{H}_{4}$ & 78 \\
\hline $\mathbf{4 g}$ & $4-\mathrm{F}-\mathrm{C}_{6} \mathrm{H}_{4}$ & 52 \\
\hline $\mathbf{4 h}$ & $3-\mathrm{F}-\mathrm{C}_{6} \mathrm{H}_{4}$ & 76 \\
\hline $\mathbf{4 i}$ & $4-\mathrm{HO}-\mathrm{C}_{6} \mathrm{H}_{4}$ & 35 \\
\hline $\mathbf{4}$ & $3-\mathrm{HO}-\mathrm{C}_{6} \mathrm{H}_{4}$ & 55 \\
\hline $\mathbf{4 k}$ & $4-\mathrm{F}_{3} \mathrm{C}-\mathrm{C}_{6} \mathrm{H}_{4}$ & 79 \\
\hline $\mathbf{4 l}$ & $4-\mathrm{MeS}^{-} \mathrm{C}_{6} \mathrm{H}_{4}$ & 93 \\
\hline $\mathbf{4 m}$ & $4-\mathrm{NC}^{-} \mathrm{C}_{6} \mathrm{H}_{4}$ & 74 \\
\hline $\mathbf{4 n}$ & $4-\mathrm{HOOC}-\mathrm{C}_{6} \mathrm{H}_{4}$ & 81
\end{tabular}

Scheme. The synthesis of 2-amino-4-aryl-4H-pyrano[3,2-c][1,2]benzoxathiine-3-carbonitrile 5,5-dioxides

DMSO-d $\left.)_{6}\right): \delta(p p m) 7.89(\mathrm{~d}, \mathrm{~J}=7.02 \mathrm{~Hz}, 1 \mathrm{H}, \mathrm{Ar}) ; 7.81$ (d, J = 7.93 Hz, 2H, Ar); 7.66-7.73 (m, 1H, Ar); 7.55-7.60 (m, 3H, NH $\left.\mathrm{NH}_{2} \mathrm{Ar}\right)$; 7.47-7.54 (m, 3H, Ar); 4.91 (s, 1H, CH).

The procedure for the synthesis of 2-amino-4-(4carboxy)-phenyl-4H-pyrano[3,2-c] [1,2] benzoxathiine-3-carbonitrile 5,5-dioxide $\mathbf{4 n}$. Reflux the solution of 1,2-benzoxathiin-4(3H)-one 2,2-dioxide $\mathbf{1}(0.198 \mathrm{~g}$, $0.001 \mathrm{~mol})$, malononitrile $2(0.066 \mathrm{~g}, 0.001 \mathrm{~mol})$ and 4-formilbenzoic acid $3 n(0.001 \mathrm{~mol})$ in ethanol $(5-10 \mathrm{~mL})$ for $1 \mathrm{~h}$. Filter the precipitate of compound $\mathbf{4} \mathbf{n}$ obtained, wash with ethanol and then dry on air.

4-(2-amino-3-cyano-5,5-dioxido-4H-pyrano[3,2-c] $[1,2]$ benzoxathiin-4-yl)benzoic acid (4n). A white fibrous precipitate. M. p. $>250{ }^{\circ} \mathrm{C}(\mathrm{EtOH})$. Anal. Calcd for $\mathrm{C}_{19} \mathrm{H}_{12} \mathrm{~N}_{2} \mathrm{O}_{6} \mathrm{~S}, \%$ : C 57.57; H 3.05; N 7.07. Found, \%: C 57.42; H 3.19; N 7.25; ${ }^{1} \mathrm{H}$ NMR (400 MHz, DMSO-d $\left.{ }_{6}\right)$ : $\delta(\mathrm{ppm}) 7.91(\mathrm{~d}, \mathrm{~J}=6.41 \mathrm{~Hz}, 3 \mathrm{H}, \mathrm{Ar}) ;$ 7.65-7.72 (m, 1H, Ar); 7.41-7.60 (m, 6H, $\left.\mathrm{NH}_{2}, \mathrm{Ar}\right)$; 4.84 (s, 1H, CH).

\section{Experimental biological part}

To study the effect of the substances on blood coagulation the Burker method $[11,12]$ was used. The method is based on determination of time of the first fibrin strands spontaneous appearance in the whole blood. The compounds under research were used as fine aqueous suspensions stabilized with Tween 80 . Suspensions were prepared in the concentrations of 1 and $3 \mathrm{mg} / \mathrm{ml}$.

As reference drugs heparin $\left(\right.$ Biolik $\left.^{\odot}\right)$ in the concentration of $1 \mathrm{U} / \mathrm{ml}$ and the solution of aminocaproic acid $\left(\right.$ Zdorovye $^{\odot}$ ) in the concentration of $1 \mathrm{mg} / \mathrm{ml}$ were used. A drop of blood was used as control.

\section{Results and discussion}

In order to broaden the number of the compounds studied in current paper we expanded the range of arenecarbaldehydes $\mathbf{3}$ and synthesized the corresponding 2-amino-4H-pyran-3-carbonitriles 4 . Thus, different substituted benzaldehydes $\mathbf{3 f}-\mathbf{n}$ were used in the abovementioned reaction conditions, in case of 4-formylbenzoic acid $3 \mathbf{n}$ the reaction readily proceeded without addition of triethylamine. The corresponding target compounds 4f-n were successfully obtained with moderate to high yields (Scheme). The structures of all compounds synthesized were confirmed by ${ }^{1} \mathrm{H}$ NMR-spectroscopy and elemental analysis.

The results of studying the effect of 2-amino-4-aryl4H-pyrano[3,2-c][1,2]benzoxathiine-3-carbonitrile 5,5-dioxides on blood coagulation are shown in Table.

According to the results of the study it was found that compounds $4 \mathrm{~g}$ and $4 \mathrm{f}$ in the concentration of $1 \mathrm{mg} / \mathrm{ml}$ significantly increased the time of blood clotting by 1.6 and 1.9 times, respectively, compared to control, indicating their anticoagulant properties. Additionally, these compounds in the concentration of $3 \mathrm{mg} / \mathrm{ml}$ showed less pronounced anticoagulant effect, i.e. no dose-dependent features were revealed.

Surprisingly enough the hemostatic activity was found for compounds $\mathbf{4 a , b , c , d , e , l , m ; ~ i t ~ r e v e a l e d ~ i n ~ a ~ s i g n i f i c a n t ~}$ decrease in the blood coagulation time compared to control. The most pronounced effect was demonstrated by compound $\mathbf{4 a}$, which significantly reduced the time of coagulation by 1.6 times in the concentration of $3 \mathrm{mg} / \mathrm{ml}$ 
Table

Continuation of Table

The effect of 2-amino-4-aryl-4H-pyrano[3,2-c][1,2] benzoxathiine-3-carbonitrile 5,5-dioxides on the coagulation time $(\Pi=4)$

\begin{tabular}{|c|c|c|}
\hline Compounds & $\begin{array}{c}\text { Concentration, } \\
\mathrm{mg} / \mathrm{ml}\end{array}$ & Coagulation time, $\mathrm{s}$ \\
\hline 1 & 2 & 3 \\
\hline $\begin{array}{c}\text { Control } \\
\begin{array}{c}\text { Aminocaproic } \\
\text { acid }\end{array}\end{array}$ & - & $143.75 \pm 4.79$ \\
\hline Heparin & 1 & $54.00 \pm 1.41^{*}$ \\
\hline 4a & 1 & $42.25 \pm 2.50^{* / * * *}$ \\
\hline 4a & 3 & $21.00 \pm 2.58^{* / * * * * * *}$ \\
\hline 4b & 1 & $95.50 \pm 4.65^{* / * * / * * *}$ \\
\hline 4b & 3 & $96.25 \pm 5.68^{* / * * * * * *}$ \\
\hline 4c & 1 & $75.75 \pm 4.35^{* / * * / * *}$ \\
\hline 4c & 3 & $84.00 \pm 3.37^{* / * * / * * *}$ \\
\hline 4d & 1 & $80.25 \pm 4.11^{* / * * / * * *}$ \\
\hline
\end{tabular}

\begin{tabular}{|c|c|c|}
\hline 1 & 2 & 3 \\
\hline 4d & 3 & $74.50 \pm 4.43^{*} / * * / * * *$ \\
\hline $4 e$ & 1 & $98.25 \pm 8.50^{*} / * * * * * *$ \\
\hline $4 e$ & 3 & $28.25 \pm 2.06 * / * * *$ \\
\hline $4 f$ & 1 & $276.50 \pm 6.99 * / * * * * * *$ \\
\hline $4 f$ & 3 & $201.25 \pm 8.54^{*} / * * * * * *$ \\
\hline $4 \mathrm{~g}$ & 1 & $210.00 \pm 10.80^{*} / * * * * * *$ \\
\hline $4 \mathrm{~g}$ & 3 & $156.25 \pm 6.99^{* *} / * * *$ \\
\hline 4I & 1 & $86.50 \pm 5.07^{*} / * * * * *$ \\
\hline $4 \mathbf{I}$ & 3 & $72.5 \pm 5.57^{*} / * * / * * *$ \\
\hline $4 m$ & 1 & $80.75 \pm 6.40^{*} / * * * * * *$ \\
\hline $4 m$ & 3 & $53.75 \pm 4.79^{*} / * * / * * *$ \\
\hline $4 n$ & 1 & $142.50 \pm 15.84^{* * * * * *}$ \\
\hline $4 n$ & 3 & $125.00 \pm 7.07^{* *} / * * *$ \\
\hline
\end{tabular}

Notes: * - the deviation is valid for control $(p \leq 0.05) ;{ }^{* *}$ - the deviation is valid for heparin $(p \leq 0.05){ }^{* * *}$ - the deviation is valid for aminocaproic acid ( $p \leq 0.05)$.

compared to the reference drug - aminocaproic acid, and at the same time, its solution in the concentration of $1 \mathrm{mg} / \mathrm{ml}$ showed the activity at the level of the reference drug. Thus, the data obtained indicate a direct dose-dependent effect on blood coagulation in this case.

Therefore, among 1,2-benzoxathiin-4(3H)-one 2,2dioxide derivatives compounds with both anticoagulant and hemostatic properties were revealed. Considering a relatively high level of these activities the effect of 2 -amino-4-aryl-4H-pyrano[3,2-c][1,2]benzoxathiine3 -carbonitrile 5,5-dioxides on the blood coagulation requires further detailed study.

\section{CONCLUSIONS}

1. A series of 2-amino-4-aryl-4H-pyrano[3,2-c][1,2] benzoxathiine-3-carbonitrile 5,5-dioxides was synthesized in the course of the three-component interaction of

1,2-benzoxathiin-4(3H)-one 2,2-dioxide, malononitrile and substituted benzaldehydes.

2. The study of the effect of the compounds obtained on the blood coagulation process revealed both anticoagulant and hemostatic substances. Namely, 2-amino-4-(4-fluoro)phenyl-4,6-dihydropyrano[3,2-c][2,1]benzoxathiin3-carbonitrile5,5-dioxide4gand2-amino-4-(3-chloro)-phenyl-4,6-dihydropyrano[3,2-c][2,1]benzoxathiin-3-carbonitrile 5,5-dioxide $\mathbf{4 f}$ significantly increased the time of blood clotting without dose-dependent changes in activity. However, for the majority of compounds the hemostatic activity with a direct dose-dependent effect was determined; it was the highest for 2-amino-4-phenyl-4,6-dihydropyrano [3,2-c][2,1]benzoxathiin-3-carbonitrile 5,5-dioxide 4a.

Conflict of Interests: authors have no conflict of interests to declare.

\section{REFERENCES}

1. Input of Isosteric and Bioisosteric Approach in Drug design / G. Ali, F. Subhan, I. Khan, N. Islam // J. of the Chemical Society of Pakistan. - 2014. - Vol. 36, Issue 1. - P. 150-169.

2. Langmuir, I. Isomorphism, isosterism and covalence / I. Langmuir // J. Am. Chem. Soc. - 1919. - Vol. 41, Issue 10. - P. $1543-1559$.

3. Erlenmeyer, H. On pseudoatoms / H. Erlenmeyer, M. Leo. // Helv. Chim. Acta. - 1932. - Vol. 15. - P. 1171.

4. Friedman, H. Influence of Bioisosteric Replacements upon Biological Activity / H. L. Friedman // National Academy of SciencesNational Research Council, Washington. - 1951. - Vol. 206. - P. 295.

5. Hansch C. Bioisosterism / C. Hansch // Intra-Science Chem. Rep. - 1974. - Vol. 8. - P. 17-25.

6. Fujita, T. A New Substituent Constant, $\pi$, Derived from Partition Coefficients / T. Fujita, J. Iwasa, C. Hansch // J. Am. Chem. Soc. 1964. - Vol. 86, Issue 23. - P. 5175-5180. https://doi.org/10.1021/ja01077a028

7. Harter, K. Anticoagulation drug therapy: a review / K. Harter, M. Levine, S. Henderson // The Western J. of Emergency Medicine. -2015. - Vol. 16, Issue 1. - P. 11-17. https://doi.org/10.5811/westjem.2014.12.22933

8. Vardanyan, R. Synthesis of Best-Seller Drugs / R. Vardanyan, V. Hruby. - Academic Press, 2016. - 868 p. https://doi.org/10.1016/ c2012-0-07004-4

9. 1,2-Benzoxathiin-4(3H)-one 2,2-dioxide - new enol nucleophile in three-component interaction with benzaldehydes and active methylene nitriles / G. V. Grygoriv, D. A. Lega, V. P. Chernykh et al. // RSC Adv. - 2018. - Vol. 8. - P. 37295-37302. doi: 10.1039/c8ra06801a

10. Synthesis of 1,2-benzoxathiine 2,2-dioxide derivatives using aliphatic aldehydes and assessment of their antimicrobial activity / G. Grygoriv, D. Lega, V. Chernykh et al. // Журн. орг. та фарм. хімії. - 2017. - Т. 15, вип. 4 (60). - P. 33-40. https://doi.org/10.24959/ophcj.17.927

11. Доклінічні дослідження лікарських засобів: метод. рек. / за ред. чл.-кор. НАН України О. В. Стефанова. - К.: Авіценна, 2001. $-528 \mathrm{c}$.

12. Медведев, В. В. Клиническая лабораторная диагностика: справ. для врачей / под ред. В. А. Яковлева / В. В. Медведев, Ю. 3. Волчек. - С.Пб: Гиппократ, 2006. - 360 с. 


\section{REFERENCES}

1. Ali, G., Subhan, F., Khan, I., Islam, N. (2014). Input of Isosteric and Bioisosteric Approach in Drug design. Journal of the Chemical Society of Pakistan, 36 (1), 150-169.

2. Langmuir, I. (1919). Isomorphism, isosterism and covalence. Journal of the American Chemical Society, 41 (10), 1543-1559. https:// doi.org/10.1021/ja02231a009

3. Erlenmeyer, H., Leo, M. (1932). On pseudoatoms. Helv. Chim. Acta, 15, 1171.

4. Friedman, H. L. (1951). Influence of Bioisosteric Replacements upon Biological Activity. National Academy of Sciences-National Research Council, Washington, 206, 295.

5. Hansch, C. (1974). Bioisosterism. Intrascience Chem. Rep., 8, 17-25.

6. Fujita, T., Iwasa, J., \& Hansch, C. (1964). A New Substituent Constant, $\pi$, Derived from Partition Coefficients. Journal of the American Chemical Society, 86 (23), 5175-5180. https://doi.org/10.1021/ja01077a028

7. Harter, K., Levine, M., \& Henderson, S. (2015). Anticoagulation Drug Therapy: A Review. Western Journal of Emergency Medicine, 16 (1), 11-17. https://doi.org/10.5811/westjem.2014.12.22933

8. Vardanyan, R., Hruby, V. (2016). Synthesis of Best-Seller Drugs. Academic Press, 868. https://doi.org/10.1016/c2012-0-07004-4

9. Grygoriv, G.V., Lega, D.A., Chernykh, V.P., Zaprutko, L., Gzella, A.K., Pawełczyk, A. \& Shemchuk, L.A. (2018). 1,2-Benzoxathiin$4(3 \mathrm{H})$-one 2,2-dioxide - new enol nucleophile in three-component interaction with benzaldehydes and active methylene nitriles. $R S C$ Adv., 8, 37295 - 37302. doi: 10.1039/c8ra06801a

10. Grygoriv, G., Lega, D., Chernykh, V., Osolodchenko, T., \& Shemchuk, L. (2017). Synthesis of 1,2-benzoxathiine 2,2-dioxide derivatives using aliphatic aldehydes and assessment of their antimicrobial activity. Žurnal organičnoï ta farmacevtičnoï hìmï̈, 15 (4 (60)), 33-40. https://doi.org/10.24959/ophcj.17.927

11. Stefanov, O. V. (2001). Doklinichni doslidzhennya likarskih zasobiv. Kyiv: «Avitsenna», 528.

12. Medvedev, V. V., Volchek, Yu. Z. (2006). Klinicheskaia laboratornaia diagnostika: spravochnik dlia vrachei. St. Petersburg: Gippokrat, 360.

Information about authors:

Grygoriv G. V., postgraduate student of the Organic Chemistry Department, National University of Pharmacy. E-mail: galkagrigoriv@gmail.com

Lega D. A., Candidate of Pharmacy (Ph.D.), teaching assistant of the Organic Chemistry Department, National University of Pharmacy.

E-mail: legus.211288@gmail.com

Shemchuk L. M., Candidate of Chemistry (Ph.D.), associate professor of the Organic Chemistry Department, National University of Pharmacy.

E-mail: orgchem@nuph.edu.ua

Maloshtan L. M., Doctor of Biology (Dr. habil.), professor, head of the Human Physiology and Anatomy Department, National University of Pharmacy.

E-mail:physio@nuph.edu.ua

Kalenichenko G. S., Candidate of Pharmacy (Ph.D.), teaching assistant of the Human Physiology and Anatomy Department, National University of Pharmacy.

E-mail: kalenichenkoas@gmail.com

Chernykh V. P., Doctor of Chemistry (Dr. habil.), Doctor of Pharmacy (Dr. habil.), professor of the Organic Chemistry Department, academician of the National

Academy of Sciences of Ukraine, National University of Pharmacy. E-mail: orgchem@nuph.edu.ua

Shemchuk L. A., Doctor of Chemistry (Dr. habil.), professor, head of the Organic Chemistry Department, National University of Pharmacy.

E-mail: orgchem@nuph.edu.ua

Відомості про авторів:

Григорів Г. В., аспірант кафедри органічної хімії, Національний фармацевтичний університет. E-mail: galkagrigoriv@gmail.com

Лега Д. О., канд. фарм. наук, асистент кафедри органічної хімії, Національний фармацевтичний університет. E-mail: legus.211288@gmail.com

Шемчук Л. М., канд. хім. наук, доцент кафедри органічної хімії, Національний фармацевтичний університет. E-mail: orgchem@nuph.edu.ua

Малоштан Л. М., д-р біол. наук, професор, завідувачка кафедри фізіології та анатомії людини, Національний фармацевтичний університет.

E-mail: physio@nuph.edu.ua

Каленіченко Г. С., канд. фарм. наук, асистент кафедри фізіології та анатомії людини, Національний фармацевтичний університет.

E-mail: kalenichenkoas@gmail.com

Черних В. П., д-р. хім. наук, д-р фарм. наук, професор кафедри органічної хімії, академік НАН України, Національний фармацевтичний університет.

E-mail: orgchem@nuph.edu.ua

Шемчук Л. А., д-р хім. наук, професор, завідувач кафедри органічної хімії, Національний фармацевтичний університет. E-mail: orgchem@nuph.edu.uа

Сведения об авторах:

Григорив Г. В., аспирант кафедры органической химии, Национальный фармацевтический университет. E-mail: galkagrigoriv@gmail.com

Лега Д. А., канд. фарм. наук, ассистент кафедры органической химии, Национальный фармацевтический университет. E-mail: legus.211288@gmail.com

Шемчук Л. М., канд. хим. наук, доцент кафедры органической химии, Национальный фармацевтический университет. E-mail: orgchem@nuph.edu.ua

Малоштан Л. Н., д-р биол. наук, профессор, заведующая кафедрой физиологии и анатомии человека, Национальный фармацевтический университет.

E-mail: physio@nuph.edu.ua

Калениченко А. С., канд. фарм. наук, ассистент кафедры физиологии и анатомии человека, Национальный фармацевтический университет.

E-mail: kalenichenkoas@gmail.com

Черных В. П., д-р хим. наук, д-р фарм. наук, профессор, академик НАН Украины, Национальный фармацевтический университет.

E-mail: orgchem@nuph.edu.ua

Шемчук Л. А., д-р хим. наук, профессор, заведующий кафедрой органической химии, Национальный фармацевтический университет.

E-mail: orgchem@nuph.edu.ua 